\title{
THE INVESTIGATION OF GROUNDWATER POTENTIAL BY VERTICAL ELECTRICAL SOUNDING (VES) APPROACH IN ARGUNI BAY REGION, KAIMANA REGENCY, WEST PAPUA
}

\author{
Langgeng Wahyu Santosa and Tjahyo Nugroho Adji \\ Environment Geography Department, \\ Faculty of Geography, Gadjah Mada University \\ E-mail: wahyus_72@yahoo.co.id and adji_tjahyo@ugm.ac.id
}

\begin{abstract}
Wis research was conducted within some villages in the surrounding area that administratively including Arguni Bay District, Kaimana Regency, West Papua. The main objective of this study is to vertically measure resistivity value of aquifer with the intention of recognizing deep groundwater potency as a source of native's domestic needs. In addition, VES method by Schlumberger electrode array was applied within 18 locations, which expectantly represent the whole area of research. The resistivity data is then interpreted by IP2W in 2.1 Geoelectric Software to entirely describe the aquifer system as well as the occurrence of groundwater. The result indicates that vertically, the aquifer system is dominated by interbedded of claystone and sandstone (argillite group) as a past marine environment mineral. In addition, geomorphological and resistivity sounding interpretation gives a viewpoint that the landforms of the research area may be typified as Structural Mountain with the slope direction is towards the island beaches. Also, structurally, the main groundwater system is fractured aquifer with very limited productivity of groundwater resources. As consequences, this aquifer is more to be an aquitard, rather than an aquifer.
\end{abstract}

Keywords: VES, Resistivity, Aquifer, Aquitard, Groundwater

\section{INTRODUCTION}

The need of groundwater supply improves continually according to the development of an area. Groundwater is subsequently considered as a contemptible resource to copiously contribute this need. However, the availibility of groundwater resources frequently insufficient to supply the water need when an area experiences enormous growth of water requirement for comercial purpose.

As a new district, Arguni Bay District is expected to rapidly develop due to the fast growing of population number in the last 5 years. Geomorphologically,
Arguni Bay District can be epitomized as Marine Depositional Coast that mainly directs its aquifer and groundwater condition. In addition, the back-upper part of this area is bounded by limestone terrain and contributes to limit the magnitude of groundwater resources. Hydrogeomorphologically, the research area encompass very scarce of groundwater prospect with very thin aquifer layer. Furthermore, resident employs springs, surface water and collects rainfall to supply their water need. This commotion seems to be very precious since they should apply water treatment before consuming the water. So that, information regarding to the availability of deep groundwater should be carried out in this 
region to accurately locate the vertical groundwater layer.

To perform the accurate production well, Vertical Electrical Sounding (VES) can be practical. Basically, VES method accepts as true that every geological layer has different resistivity values. Beside the rock type, resistivity value diverges in relation to the saturation and chemical composition of water encompassing its rock interstices (Todd, 1980; Zohdy, 1980). According to the above principle, subsequently the aquifer layer may be interpreted and the location of deep groundwater may be defined as fundamental information to place a production well. Then, the main objectives of this research are to characterize aquifer condition and to locate the groundwater availibility as a resource for native domestic necessitate.

Aquifer is a saturated geological formation that can store and transmit significant quantities of water under ordinary potential gradient (Todd, 1980). Here, significant means that its quantity must able to supply wells or springs for a long time. In addition, Fetter (1988) introduces that unconsolidated sand, gravel, sandstone, porous limestone and dolomite, basalt flow, fractured plutonic and metamorphic rock are examples of an aquifer. According to the geological perspective, aquifer may be grouped into three types, there are (1) unconfined aquifer when the water table forms the upper boundary; (2) confined aquifer when the hydraulic head lies above the base of the upper confining layer and is generally referred to as piezometric surface; (3) perched aquifer when it occur above an unconfined aquifer, but the downward movement of water is impeded by a discontinuous confining layer (Acworth, 2001).
According to Fetter (1988), sediment rock will result to the complex hydrogeological system in terms of distribution of recharge and discharge zone. For instance, clay sediment may impede groundwater flow since it has very low hydraulic conductivity value. As clarified above, it clearly seems that geomorphology and geological condition strongly impinges on aquifer characteristics of an area. Next, according to Walton (1970), litological and geological structure should be considered as very essential information in order to evaluate the groundwater resources.

Geoelectric survey or Vertical Electrical Sounding (VES) is a geophysical method that is able to predict the subsurface condition including groundwater and aquifer of an area (Zohdy, 1989). VES provides information concerning the vertical succession of different conducting zones and their individual thicknesses and resistivity. For this reason, the method is practically valuable for investigations on vertically layer of the subsurface. Also, VES survey gives information concerning geological condition including rock nature, layer thickness as well as saturation condition of the formation. Therefore, this method may be able to support groundwater investigation.

In the electrical sounding method, the midpoint of the electrode configuration is fixed at the observation station while the length of the configuration is gradually increased. As a result, the current penetrates deeper and deeper, the apparent resistivity being measured each time the current electrodes are moved outwards (Koefoed, 1977). For Schlumberger array, apparent resistivity is given: 
$\varrho_{\mathrm{a}}=\pi \mathrm{R}\left(\mathrm{a}^{2} / \mathrm{b}-\mathrm{b} / 4\right) \quad \ldots$. (Keller and

Frischnechk, 1979)

where,

$$
\begin{aligned}
\mathrm{a}= & \text { half current electrode separation } \\
& \text { (meter) } \\
\mathrm{b}= & \text { potential electrode spacing (meter) } \\
\mathrm{R}= & \text { Resistance }(\mathrm{Ohm})=\mathrm{V} / \mathrm{I} \\
\mathrm{V}= & \text { Potential (Volt) } \\
\mathrm{I}= & \text { current (Ampere) }
\end{aligned}
$$

The Schlumberger configuration is preferable to the Wenner array for depth sounding because the field procedure is quicker and simpler and master curves and software are more readily available for result analysis. The data obtained is usually plotted as a graph of apparent resistivity against half electrode spacing for the
Schlumberger array. The electrode spacing at which inflection occurs on the graph provides an idea of the depth to the interface. A useful approximation is that the depth of the interface is equal to two thirds (2/ 3) of the electrode spacing at which the point of inflection occurs (Vingoe, 1972). This approximation has found useful applications in computer iterative modelling.

Table 1 gives the resistivity values of ordinary rocks, soil materials and chemicals (Keller and Frischknecht 1979, Daniels and Alberty, 1966 in Loke, 1999). By looking at Table 1, it is clearly shown that igneous and metamorphic rocks typically perform high resistivity values due to their degree of fracturing, and the percentage of the fractures filled by ground water. In addition, sedimen-

Table 1. Resistiviy and Conductivity for Geological Formation

\begin{tabular}{|l|l|l|}
\hline \multicolumn{1}{|c|}{ Material } & Resistivity $(\Omega \bullet m)$ & Conductivity (Siemen/m) \\
\hline $\begin{array}{l}\text { Ionenus a nd Metamornhic Rocks } \\
\text { Granite }\end{array}$ & $5 \times 10^{3}-10^{6}$ & $10^{-6}-2 \times 10^{-4}$ \\
Basalt & $10^{3}-10^{6}$ & $10^{-6}-10^{-3}$ \\
Slate & $6 \times 10^{2}-4 \times 10^{7}$ & $2.5 \times 10^{-8}-1.7 \times 10^{-3}$ \\
Marble & $10^{2}-2.5 \times 10^{8}$ & $4 \times 10^{-9}-10^{-2}$ \\
Quartzite & $10^{2}-2 \times 10^{8}$ & $5 \times 10^{-9}-10^{-2}$ \\
Sedimentarv Rocks & & \\
Sandstone & $8-4 \times 10^{3}$ & $2.5 \times 10^{-4}-0.125$ \\
Shale & $20-2 \times 10^{3}$ & $5 \times 10^{-4}-0.05$ \\
Limestone & $50-4 \times 10^{2}$ & $2.5 \times 10^{-3}-0.02$ \\
Soils and waters & & \\
Clay & $1-100$ & $0.01-1$ \\
Alluvium & $10-800$ & $1.25 \times 10^{-3}-0.1$ \\
Groundwater (fresh) & $10-100$ & $0.01-0.1$ \\
Sea water & 0.2 & 5 \\
Chemicals & & $1.102 \times 10^{7}$ \\
Iron & $9.074 \times 10^{-8}$ & 1.413 \\
0.01 M Potassium chloride & 0.708 & 1.185 \\
0.01 M Sodium chloride & 0.843 & 0.163 \\
0.01 M acetic acid & 6.13 & $1.429 \times 10^{-17}$ \\
Xylene & $6.998 \times 10^{16}$ & \\
\hline
\end{tabular}

Source: Keller \& Frischknecht (1979); Daniels \& Alberty (1966 in Loke, 1999) 
tary rocks, which usually are more porous and have higher water content, in general have lower resistivity values. Wet soils and fresh ground water have even lower resistivity values. Clayey soil normally has a lower resistivity value than sandy soil. Furthermore, resistivity of ground water varies from 10 to 100 Cmeter. depending on the concentration of TDS. Note the low resistivity (about 0.2 Cmeter) of sea water due to the relatively high salt content. This makes the resistivity method an ideal technique for mapping the saline and fresh water interface in coastal areas. The resistivity values of several industrial contaminants are also given in Table 1.

\section{METHODS}

This VES survey was conducted within some villages that administratively include Arguni Bay District, Kaimana Regency. Due to the limitation of detail scale on geomorphology and geological map, then Google Earth image interpretation was applied to generally introduce research area condition. In addition, geoelectrical sounding tool, tape meter and GPS are the main field work equipments, while notebook computer and IP2Win software are required as the post-field work equipments.

The points of VES measurement are approached by purposive sampling within

Table 2. The distribution of VES measurement

\begin{tabular}{|l|c|c|l|c|l|}
\hline \multirow{2}{*}{ Point } & \multicolumn{2}{|c|}{ Coordinate UTM 53M } & \multirow{2}{*}{ Orientation } & $\begin{array}{c}\text { Dept of } \\
\text { Penetration (m) }\end{array}$ & \multirow{2}{*}{ Villages } \\
\cline { 2 - 3 } & Easting & Northing & & 100 & Funiara \\
\hline G1 & 365267 & 9665836 & West - East & 150 & Funiara \\
\hline G2 & 365118 & 9665817 & North - South & 150 & Wetuf \\
\hline G3 & 364863 & 9682674 & North - South & 100 & Wetuf \\
\hline G5 & 364890 & 9682753 & West - East & 50 & Weswasa Baru (Efara) \\
\hline G6 & 365406 & 9676387 & West - East & 75 & Moyana \\
\hline G7 & 376118 & 9661087 & North - South & 100 & Bayeda \\
\hline G8 & 375160 & 9662687 & North - South & 100 & Tugarni (Gusimawa) \\
\hline G9 & 375076 & 9663073 & West - East & 100 & Tugarni (Gusimawa) \\
\hline G10 & 375246 & 9663314 & West - East & 150 & Afu-afu \\
\hline G11 & 375304 & 9663451 & West - East & 100 & Afu-afu \\
\hline G12 & 364122 & 9666003 & North - South & 150 & Wanggita \\
\hline G13 & 364208 & 9666029 & North - South & 150 & Wanggita \\
\hline G14 & 364225 & 9666138 & West - East & 100 & Wanggita \\
\hline G15 & 364369 & 9666178 & West - East & 75 & Bofuer \\
\hline G16 & 364346 & 9666054 & West - East & 75 & Bofuer \\
\hline G17 & 364532 & 9666002 & North - South & 75 & Warwasi \\
\hline G18 & 364585 & 9665875 & North - South & 100 & Warwasi \\
\hline
\end{tabular}

Source: August 2006 survey 


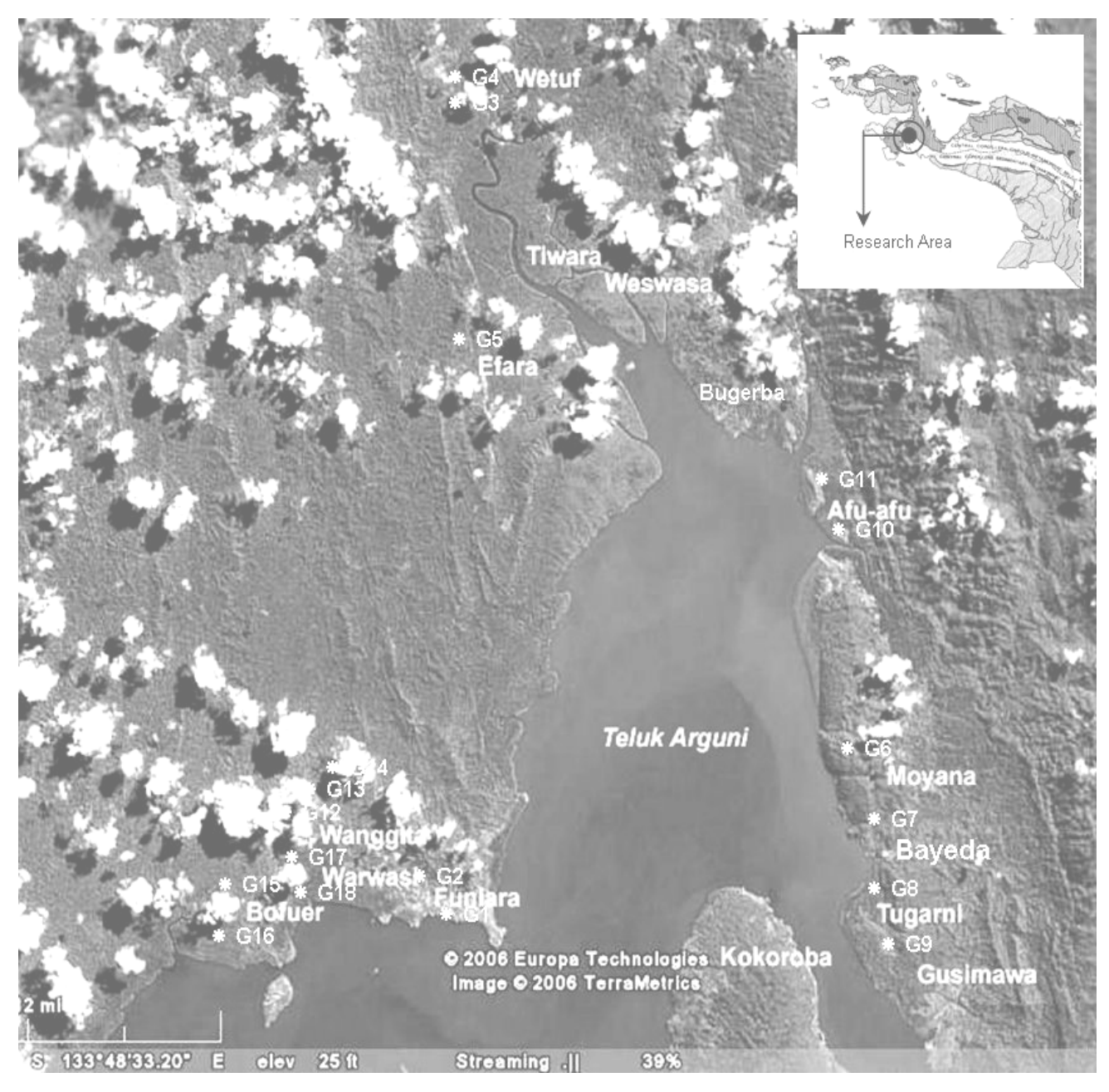

Figure 1. Field VES Points Plotting

every village with the intention that representative to the vertical resistivity values up to approximately $100-150$ meters depth. Additionally, VES conducted in 18 point by depth penetration up to 150 meters. Next, Table 2 shows the distribution of any points VES measurement, while its spatial distribution is illustrated in Figure 1.

Afterwards, to define the distinctiveness of aquifer system as well as the occurrence of groundwater resources; hydrostratum analysis is conducted by reconstructing the aquifer layer with the help of
IP2Win software (Moscow State University, 2001). This analysis is also based on the resistivity values and layer aquifer thickness correlation according to O'Neill Schlumberger (Zohdy, 1980). Besides that, descriptive analysis is also applied to study the correspondence between resistivity values, layer thickness, and geology-geomorphology conditions.

\section{RESULTS AND DISCUSSION}

\section{Geomorphology and Geology}

According to Bemmelen (1970), the Papua Island was formed by tectonical 
forces resulting from the shift of the Australian continent towards the Melanesian submerged block. The sediments lying in between were folded, and locally some volcanic activity took place. The greater part of the island is of Oligo-Miocene age; the uplift of the mountain areas began at that time and continued up till Plio-Miocene and recent times. Traversing the island from south to north, we come across the large and flat, low-lying Digul-Fly Depression, bordering the very steeply rising Central Mountain Range. Locally in this range we meet with some elevated valleys, such as the Wissel Lakes, the Kamu Valley and the Balim Valley. Near the border with Papua
New Guinea $\left(141^{\circ} \mathrm{E}\right)$ some local volcanic activity is present; it extends to the east, where it becomes more important. Northward on the mainland the low-lying Lake Plain is found, bordered by the Northern Dividing Range. The northern coastal plain forms part of the Mamberamo Trough; it is flat except for some parts on the eastern side, where the border with the Melanesian platform is marked by mountains, such as the Cyclop Mountains.

In the Bird's Head, the tectonic movements have been highly influenced by the pressure and the folding of the Bandaarc system in the west. In the northern parts

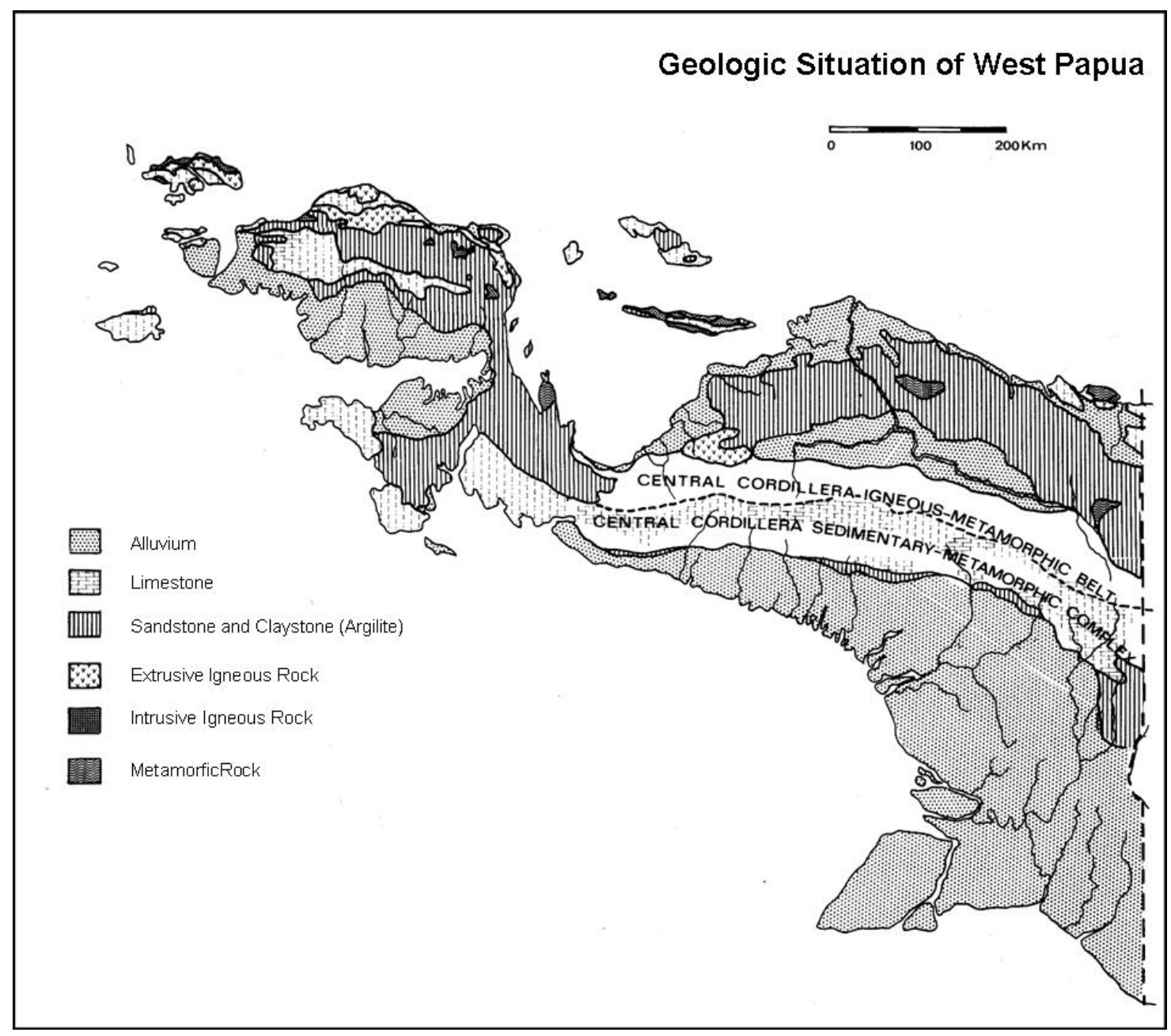

Figure 2. The distribution of Papua's Rock Types (Petocz, 1987) 
of the Arfak Mountains locally some old volcanic units are found. In the transitional area between the bended part of the Central Mountain Range system and the Tamrau Mountains some valleys occur, such as the Kebar Plains and the Angi Lakes. The oldest Paleozoic Formations are represented by the Permian-Carboniferous sediments in the Central Range and the metamorphic rocks (schists, gneiss and basaltic intrusional material) on the northern flank of that range as well as in the middle of the Northern Dividing Range, and in the middle of the northern Bird's Head and on some of the islands (e.g. Japen and Waigeo). Crystalline intrusions and metamorphic rocks of the Cyclop Mountains represent much older formations. Mesozoic (Jurassic to Senonian) sediments are present on both sides of the Paleozoic rocks of the Central Range, but predominate in the highly elevated valleys. The New Guinea limestone of the Tertiary period (Paleocene- Mi- ocene) forms extensive mountain areas in the Central Range and large parts in the centre of the Bird's Head, and also parts of the islands in Geelvink Bay. The PlioPleistocene Formations (silt and sandstones, limestones, marls and shales) are found on the southern flanks of the Central Range: they cover large parts of the Northern Dividing Range.

In addition, Petocz (1987) points out that the oldest Paleozoic Formation represented by Permian-Carboniferous found in a large number in the central mountain, besides metamorphic, schist and gneiss rocks type. Basalt-intrusion rock found in the northern part of Central Mountain, while the older rock (crystalline) found in Cyclops Mountain (closed to Mamberamo). Tertiary limestone also found in large number in the Central Papua, around Bird's Head, and the surrounding small islands. The most dominant outcrop rocks (Plio-

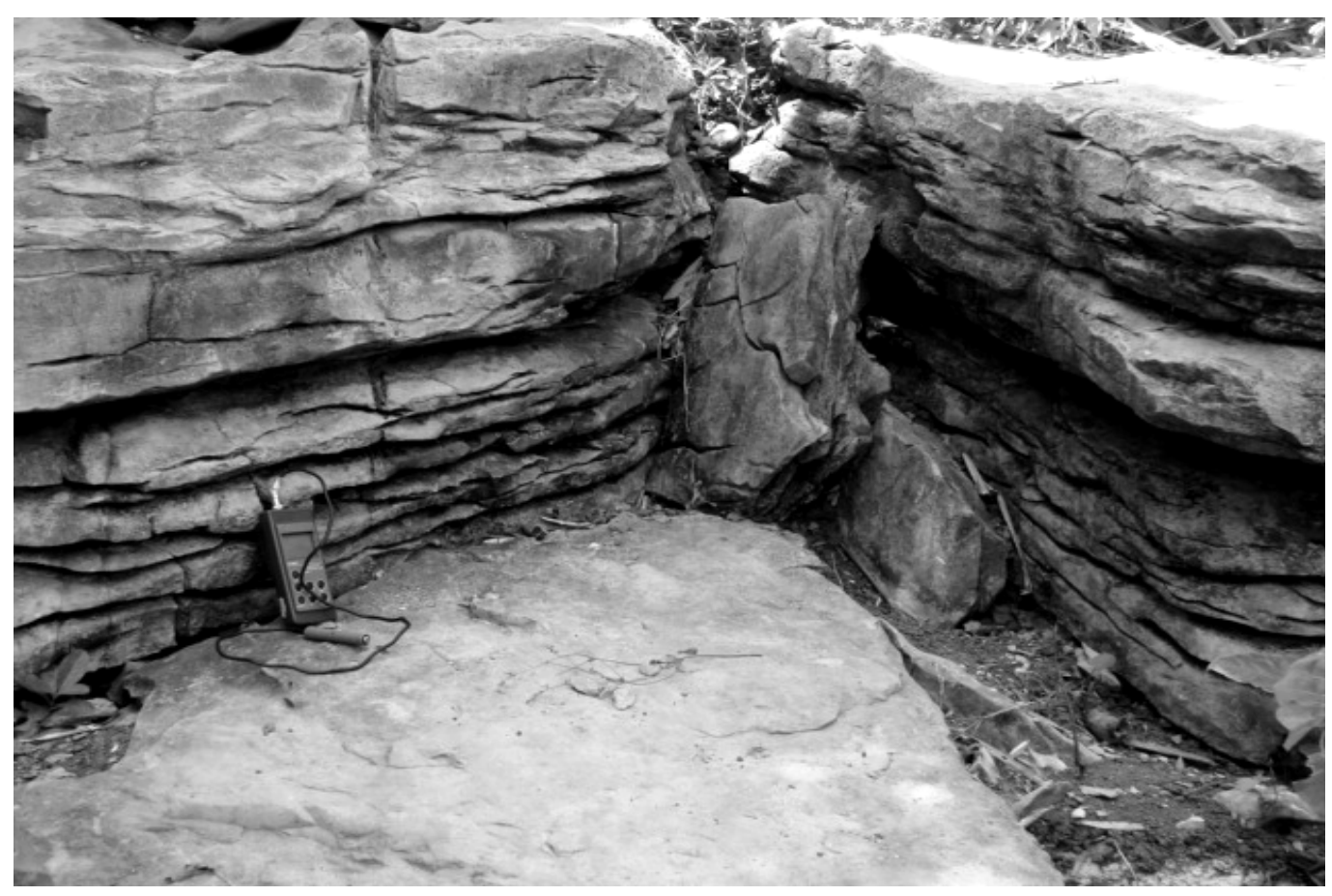

Figure 3. The occurrence of Sediment-Argillite Rock in Arguni Bay District 
pleistocene) are sediment rocks such as sandstone, silt, shale, limestone and marl, as it distribution shown in Figure 2. According to the field investigation, the geology of research area that include the western part of central mountain may be grouped into 2 dominant rock types: (1) the western part mainly consist of sandy sediment (sandstone) that interbedded with claystone; and (2) the eastern part that composed by limestone that lies above sediment rock. In the Western Arguni Bay, it seems that sandstone and claystone has already amalgamated as a new agregat, that known as Argillite Rock (Figure 3). Argillite may be classified as clastic sedimentary rock, colored by grey to dark, very fine texture, with very fine grain size, with fractured and fossilized inside. This rock formerly formed in marine, lagoon, or lacustrine environments.

\section{Aquifer system and the occurence of groundwater}

According to the VES measurements in 18 positions as listed in Table 2, then analysis and interpretation was conducted by using the help of IP2Win. The results of vertical aquifer stratum afterwards are shown in Figure $4-10$ below.

By looking at Figure 4, the vertical aquifer stratum of Funiara Village may be grouped into 3 layers, which are: (1) top layer of unsaturated soil or only consist of soil moisture which is indicated by the resistivity value less than $20 \mathrm{~W}$ meter until the depth of approximately 5 meters;(2) the second layer is a product of argillite weathering with very limited groundwater resources and usually associated with basin topography. This layer is typified by resistivity value of 10 $20 \mathrm{~W}$ meter with the depth between 5 to 10 meter below earth surface, and (3) the fractured bedrock aquifer with poor groundwater resources by resistivity value $<10 \mathrm{~W}$ meter, depth below 10 meters.

According to the vertical distribution of resistivity value, field investigation as well as the occurrence of rock outcrop found in the field, the aquifer layer of Wetuf Village also be grouped into 3 layers (Figure 5), which are: (1) top layer of

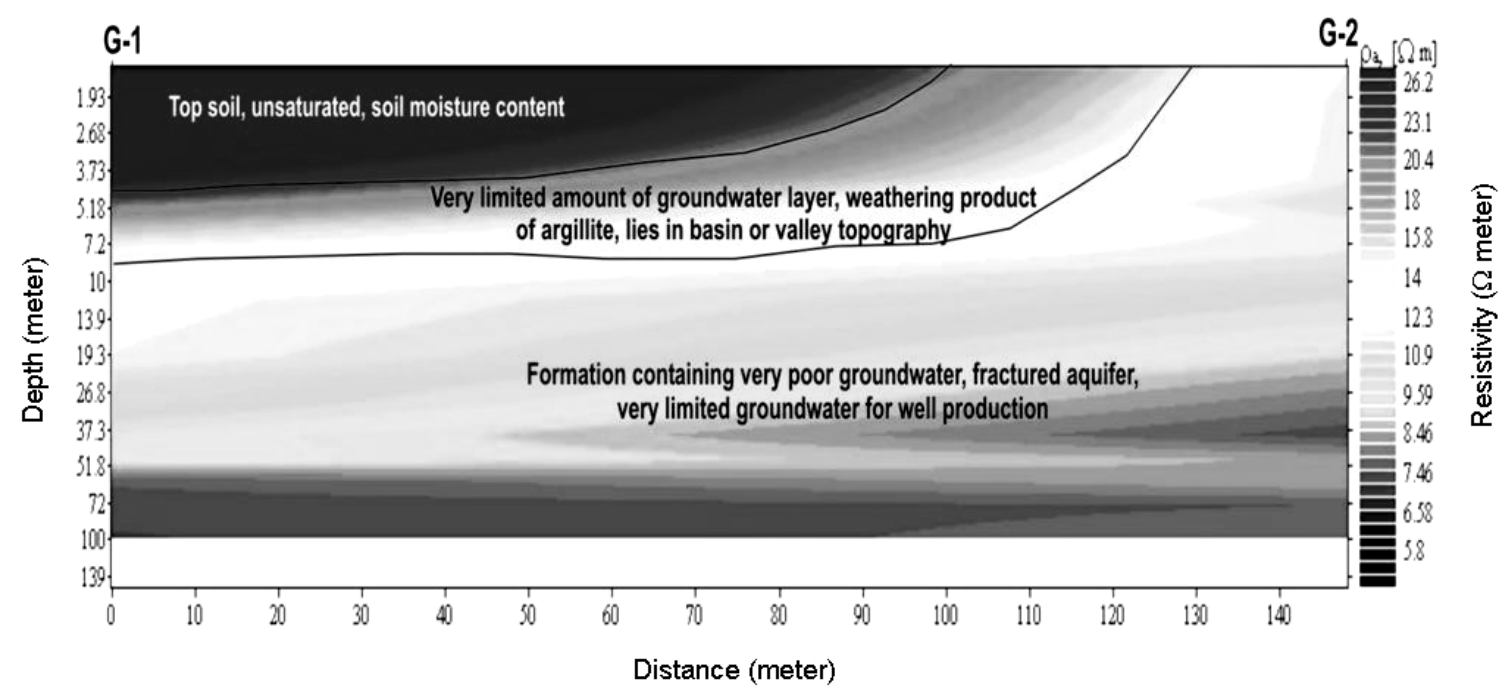

Figure 4. The vertical aquifer stratum of Funiara Village (G1-G2) 


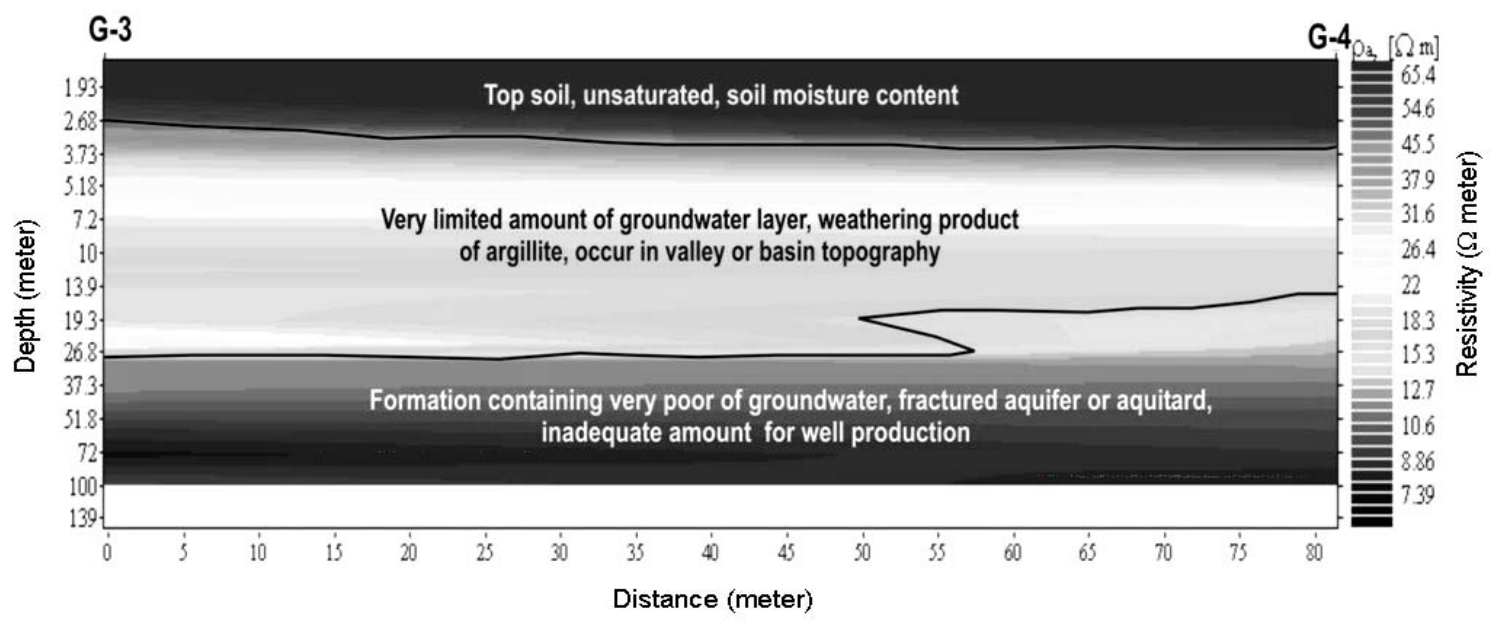

Figure 5. The vertical aquifer stratum of Wetuf Village (G3-G4)

unsaturated soil which is indicated by the resistivity value less than $30 \mathrm{~W}$ meter until the depth of approximately 5 meters; (2) the second layer may contain groundwater but in limited amount. The resistivity value is around $15-30 \mathrm{~W}$ meter with the depth between 5 to 25 meter below earth surface; and (3) the bedrock of fractured argillite rock below the depth of 25 meters, poor of groundwater with resistivity value of $<15 \mathrm{~W}$ meter.
Figure 6 demonstrates that vertical aquifer distribution of Tugarni Village generally may be divided into 2 layers. The first one is layer with resistivity value $>15 \mathrm{~W}$ meter as a fractured argillite bedrock, so that groundwater moves according to the structure. In the top subsurface, this layer seems very dry because no groundwater trapped in the layer due to the restraint of fracture to occur. However, starting from the depth of 25 meters, the resistivity val-

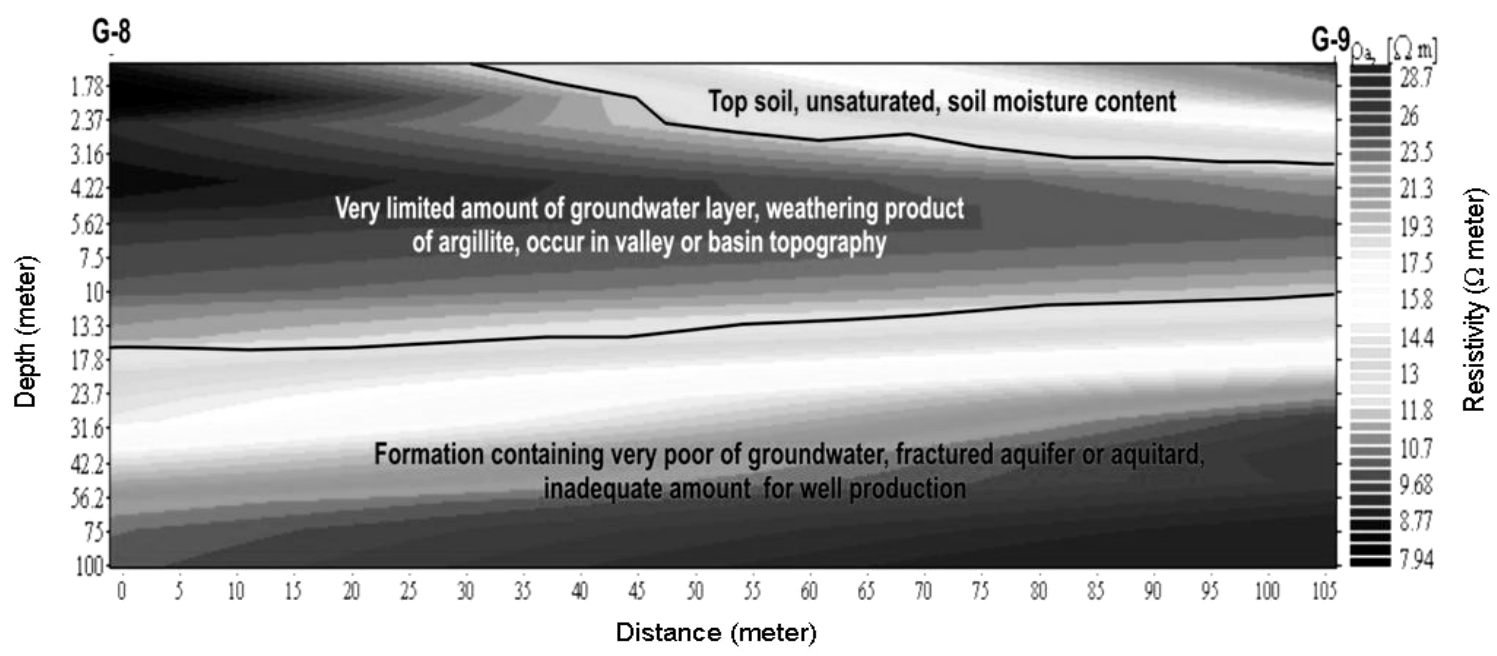

Figure 6. The vertical aquifer stratum of Tugarni Village (G8-G9) 


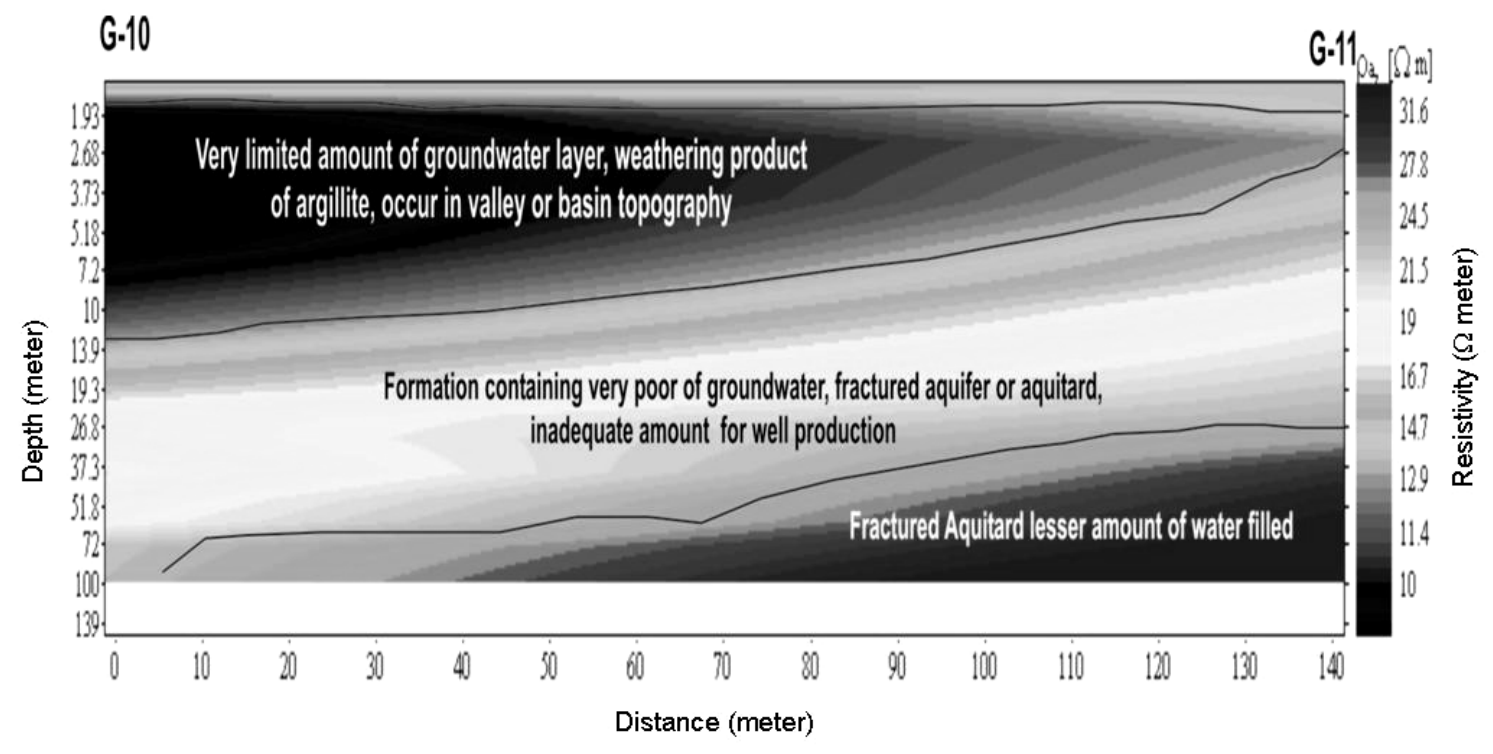

Figure 7. The vertical aquifer stratum of Afu-Afu Village (G10-G11)

ues decrease and indicate the increasing amount of groundwater within the layer. Next, the second layer is a groundwater contained aquifer, typified by resistivity value of $<15 \mathrm{~W}$ meter. This layer comprised by bedrock weathering product.

By considering Figure 7 , the vertical aquifer stratum of Afu-Afu Village may be grouped into 3 layers, which are: (1) the first layer is a product of argillite weathering with some degree of groundwater resources and usually associated with basin topography. The thickness of this layer is approximately 12 meters. This layer is typified by resistivity value of $<15 \mathrm{~W}$ meter; (2) the fractured bedrock aquifer with deprived groundwater resources by resistiv-

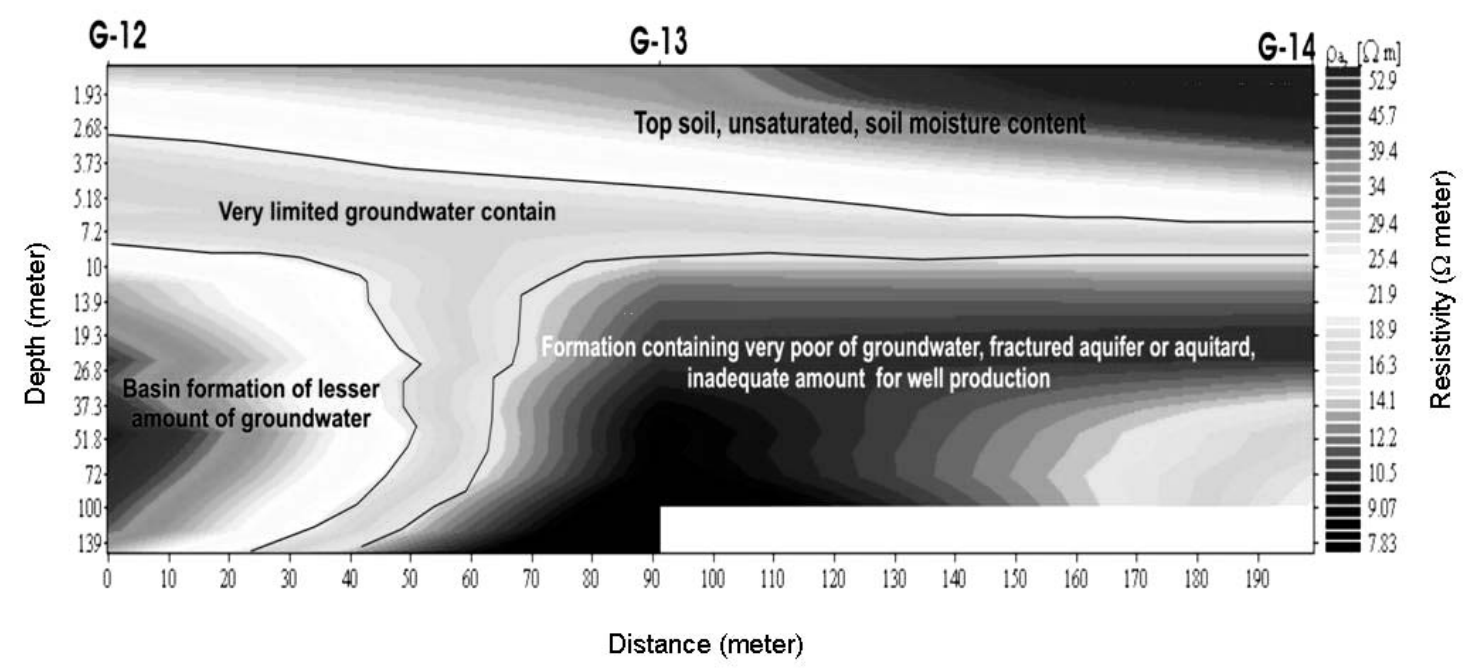

Figure 8. The vertical aquifer stratum of Wanggita Village (G12-G13-G14) 


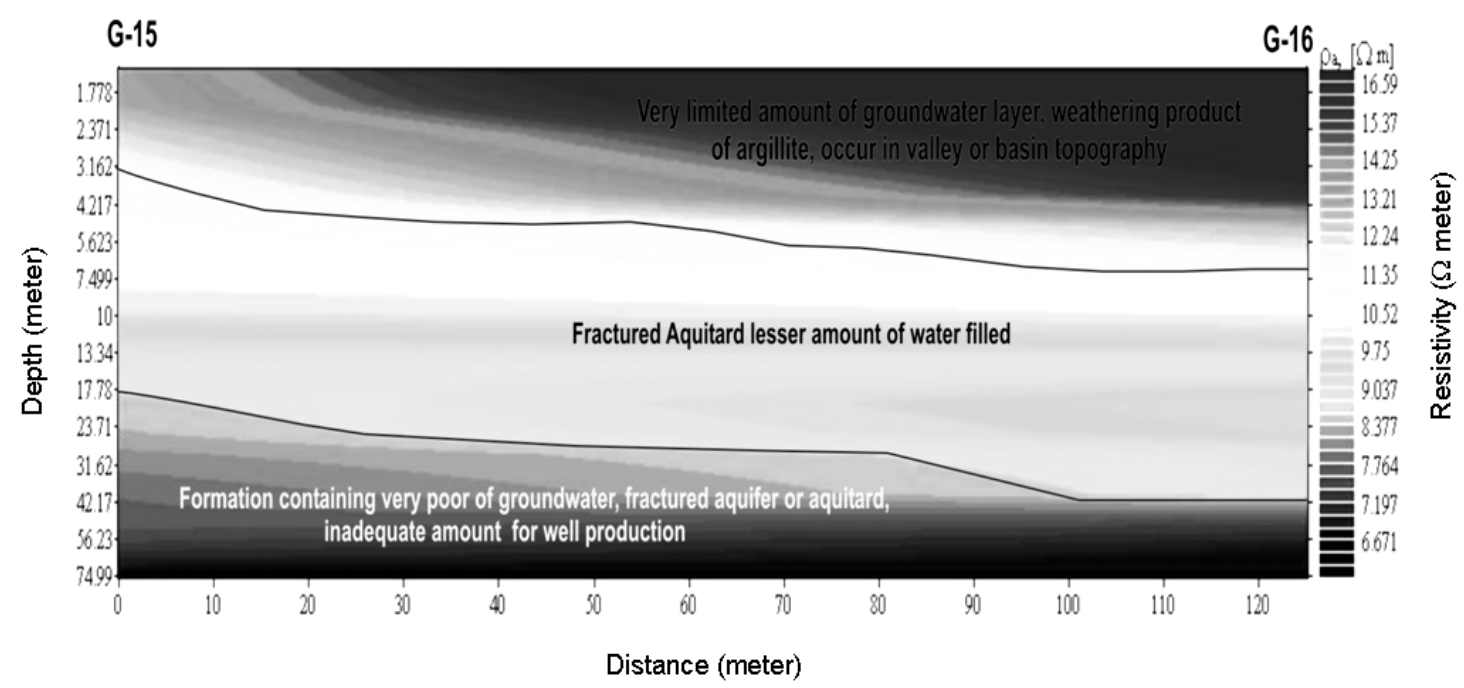

Figure 9. The vertical aquifer stratum of Bofuer Village (G15-G16)

ity value between $15-25 \mathrm{~W}$ meter, depth between 12 - 60 meters; and (3) bedrock, poor of groundwater, starting from 30 meters below the earth surface.

In accordance with Figure 8 , in Wanggita, first upper layer is reconstructed as a dry top soil up to 5 meters depth, while water table is found in the depth of 5 meters (second layer) as consist of weathered layer with resistivity value of $>15 \mathrm{~W}$ meter. This layer continues until the depth of 30 meters. Lastly, the third layer is a poor groundwater bedrock stratum.

In Bofuer village, according to Figure 9 , it obviously seems that there are two layers that potential to amass groundwater, which are: first top layer with the resistivity value of $>10 \mathrm{~W}$ meter occurs in basin topography, while the second is the layer with resistivity value below $10 \mathrm{~W}$ meter as a fractured aquifer.

The aquifer reconstruction in Warwasi village (Figure 10) confirms that
2 aquifer layers with different capability in storing groundwater, which are: (1) the top layer as a weathering product accumulated in narrow valley topography with very limited groundwater storage. The resistivity value is $>10 \mathrm{~W}$ meter and found until 25 meters depth; (2) bedrock fractured aquifer, poor of groundwater, with resistivity value of $<10 \mathrm{~W}$ meter. This layer found somewhere below 30 meters depth.

In line with the all seven stratum cross sections, it may be considered that the subsurface geological material around Arguni Bay performs somewhat different situation. Subsequently, this condition impinges on the thickness and occurrence of the formation containing groundwater. In general, groundwater found in the region of valley or basin topography closed to the beaches. However, because the material is a product of argillite weathering, so that it is acceptable to be considered as an aquitard rather than an aquifer. In addition, this material of weathering product in the upper part is based by fresh bedrock under- 


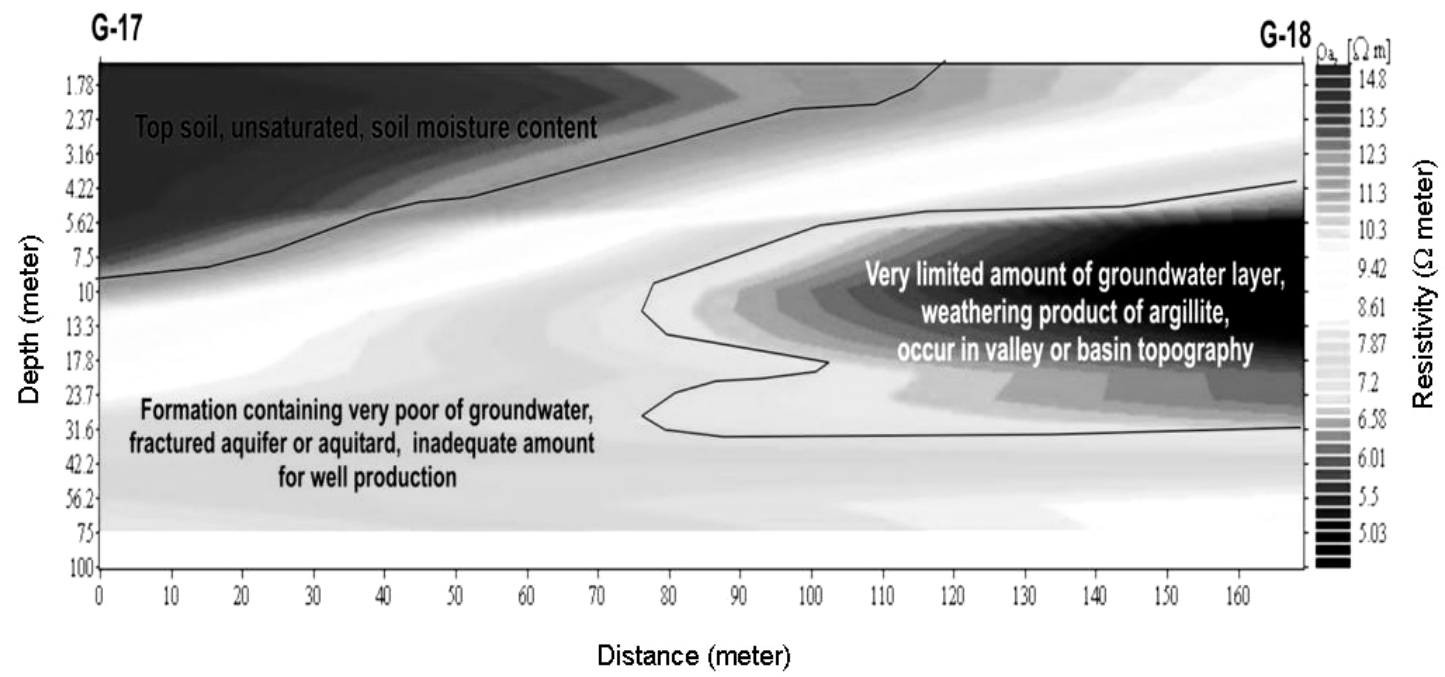

Figure 10. The vertical aquifer stratum of Warwasi Village

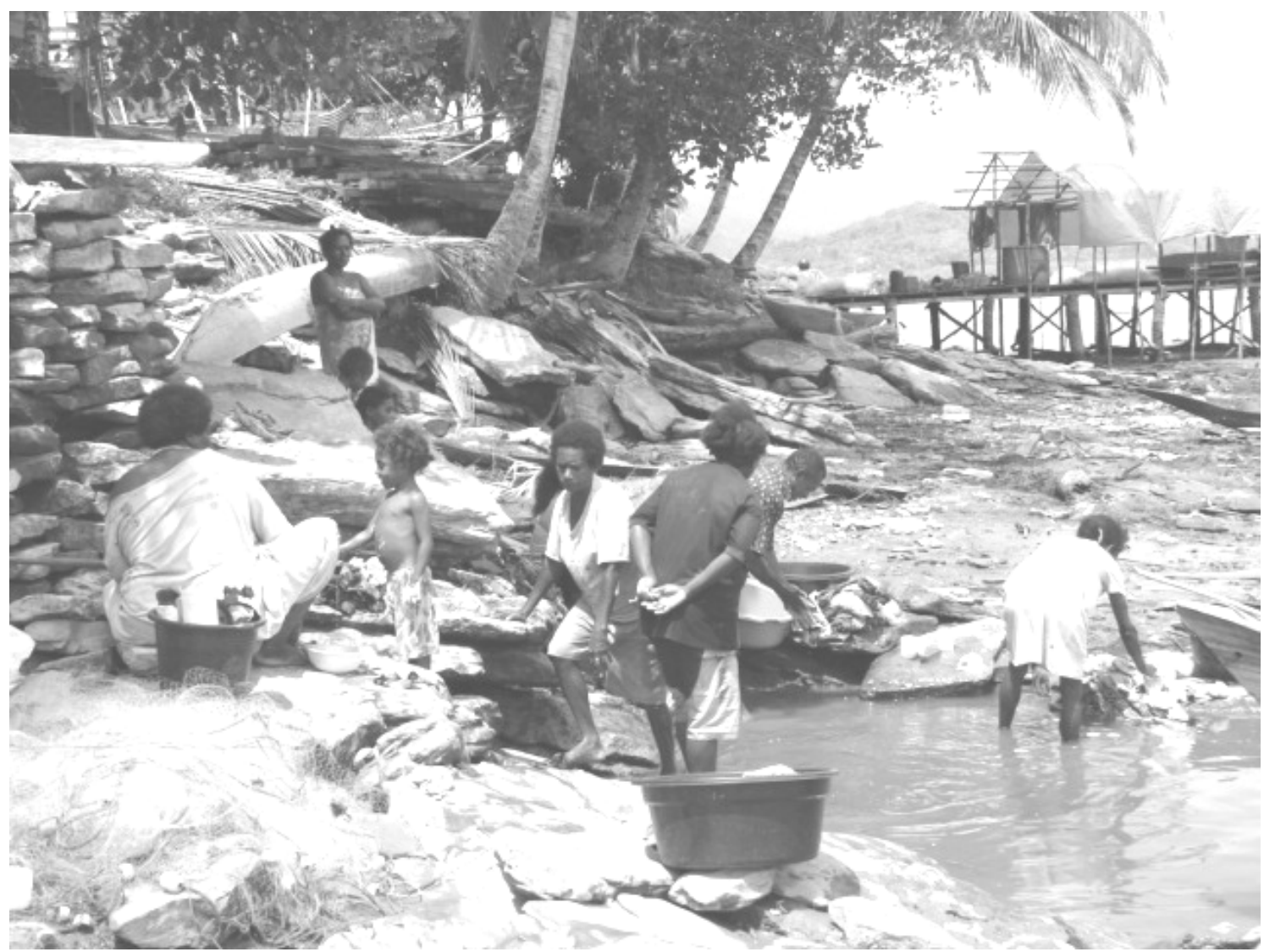

Figure 11. Spring at Weswasa Village flows out through break of slope of argillite fractured, conductivity more than 4000 imhos cm. Used as bathing and washing. (Photo: Santosa, 2006) 
neath. This material might reach 25 meters thickness from the earth surface. Meanwhile, as a result of fracturing within the bedrock, the groundwater within the top layer only found in very limited amount and only locally distributed within the basin topography.

Furthermore, due to the occurrence of fractured bedrock material and the dip direction of the layer, groundwater flows to the sea and found near the beaches as springs and seepages as demonstrated in Figure 11. In addition, VES survey only figures out the layer and the possibility of groundwater contain.

\section{CONCLUSION}

(1) In accordance with the geomorphology condition investigation and the VES measurement and analysis, it is concluded that all villages including Arguni Bay District, generally lies on low structural hills which are composed by argillite group bedrock material. The depth of the bedrock is approximately 10 meter below earth surface with the steep slope toward the beaches.

(2) The argillite bedrock is composed by interbedded of sandstone and claystone. These rocks may be classified as clastic sedimentary rock, colored by grey to dark, very fine texture, very fine grain size, with fractured and fossilized inside. This rock formerly formed in marine, lagoon, or lacustrine environments.
(3) Structurally, the main aquifer system is fractured aquifer with very low productivity. Groundwater only found locally within fracture, and performs low permeability value ranging from $10^{-9}$ to 10 ${ }^{12} \mathrm{~cm} /$ second.

(4) The stratigraphy cross sectional analysis points out that the research area and its surrounding comprises different vertical aquifer layers arrangement. The layers arrangement then affects the occurrence and the thickness formation containing groundwater. Groundwater usually found in the valley topography lies between hills very close to the beaches and being trapped within the weathered material of argillite rock. Due to the clay content of the material, it seems that the material may be considered as aquitard. The depth of this layer from ground surface is approximately 25 meters depending on topographical section. In general, groundwater resources condition is classified as poor groundwater prospect and every year constantly performs water shortage.

\section{ACKNOWLEDGEMENTS}

Special thanks are due to Public Works and Transportation Bureau of Kaimana Regency for full financial support of this project and a good cooperation during filed work. Hopefully Allah SWT blesses you all. Amen. 


\section{REFERENCES}

Acworth, R.I., 2001. Electrical Methods in Groundwater Studies, Short Course Note. School of Civil and Environmental Engineering, UNSW. Sydney, Australia

Bemmelen, R.W. van, 1970. The Geology of Indonesia. General Geology of Indonesia and Adjacent Archipelagoes. Government Printing Office. The Haque

Fetter, C.W., 1988. Applied Hydrogeology. $2^{\text {nd }}$ Edition, MacMillan Publishing Company, New York

Freeze, R.A. and Cherry, J.A., 1979, Groundwater, Englewood Cliff, Prentice Hall Inc., New York

Keller, G. V., and Frischnechk, F.C., 1979. Electrical Methods in Geophysical Prospecting. Pergamon Press

Koefoed, O., 1977. Geosounding Principles 1: Resistivity Sounding Measurements. Elsevier, Amsterdam, 277pp.

Looke, M.H., 1999. Electrical Imaging Surveys for Environmental and Engineering Studies - A Practical Guide to 2D and 3D Survey.Cangkat Minden Lorong 6, Minden Heights, 11700 Penang, Malaysia (mhoke@pc.jaring.my), Downloaded from http://www.abem.se

Moscow State University, 2001. IP2WIN Version 2.1., IP_Res2, IP_Res3, User's Guide, Moscow

Petocz, R.G., 1987. Conservation and Development in Irian Jaya, A Strategy for Rational Resources Utilization, WWF/IUCN, World Concervation Centre, Avenue du Mont Blanc CH1196 Gland, Switzerland

Todd, D.K., 1980. Groundwater Hydrology, John Wiley and Sons, New York

Vingoe, P., 1972. Electrical resistivity surveying. ABEM geophysical memorandum 5/72, pp. 1 13.

Wahyu Santosa, L., 2006. "Kajian Hidrogeomorfologi Mataair di Sebagian Lereng Barat Gunungapi Lawu”. Forum Geografi, Vol. 20, No. 1, Juli 2006. Hlm 68-85.

Walton, W.C., 1970. Groundwater Resources Evaluation, McGraw-Hill Book Company, New York

Zohdy, A. Ar., 1980. Application of Surface Geophysics to Groundwater Investigation, U.S. Department of the Interior, Washington D.C.

Zohdy, A. Ar., 1989. A New Method for the Automatic Interpretation of Schlumberger and Wenner Sounding Curves. Geophysics 54 (2), p 245-253 